Al-Ishlah: Jurnal Pendidikan - ISSN: 2087-949o (p); 2597-940X (e)

Vol. 11, No. 1 (2019)

\title{
IMPROVING STUDENTS' WRITING SKILL OF DESCRIPTIVE TEXT BY USING EXAMPLE NON-EXAMPLE STRATEGY AT GRADE $X$ OF VOCATIONAL MADRASAH ALIYAH ADZQIA BELIMBING
}

\author{
Aprizon \\ STKIP Air Molek \\ Email: aprizon08@gmail.com \\ Puspa Gundary \\ STAI Hubbulwathan Duri \\ Email: puspagundary@yahoo.com
}

\begin{abstract}
The purposes of this research were to find out whether example non-example strategy can improve the students' writing skill on descriptive, and to find out what factors influence the improvement of the students' writing skill in writing descriptive text. This research was Classroom Action Research. This research was conducted in two cycles, which each cycle had three meetings. It was conducted from August $1^{\text {st }}$ until August $31^{\text {th }}$.The researcher gathered the data in each cycles from observation checklist, field notes, interviews, and writing test. After analyzing the data, the researcher found that Example non-example strategy was able to improve the students' writing skill of descriptive text through the process of comprehending the students, and assisting the students while they were writing. As the results, the students could improve their writing skill which involved the improvement of mean score of writing indicators; vocabulary, content/ideas, and organization. Moreover, it could be seen from the improvement of their mean score of basic score (56), test I (h62.5), and test II (79.4). Furthermore, the factors that influence the improvement of the students' writing skill involved materials, media, and learning strategy. To sum up, the implementation of Example non-example strategy in teaching writing of descriptive text could provide positive results on their writing skill.
\end{abstract}

Penelitian ini bertujuan untuk mendapatkan jawaban tentang apakah strategi Example Non-example dapat meningkatkan kemampuan menulis siswa pada teks deskriptif, dan untuk mengetahui faktor-faktor apa yang mempengaruhi peningkatan kemampuan siswa dalam menulis teks deskriptif. Penelitian ini adalah penelitian tindakan kelas. Penelitian ini dilakukan dalam dua siklus. Setiap siklus terdiri dari tiga kali pertemuan. Penelitian ini dilaksanakan pada tanggal 1 Agustus sampai dengan 31 Agustus 2016. Peneliti mengumpulkan data melalui lembar observasi, catatan lapangan, wawancara dan tes menulis. Dari 
Al-Ishlah: Jurnal Pendidikan - ISSN: 2087-949o (p); 2597-940X (e)

Vol. 11, No. 1 (2019)

hasil penelitian, peneliti menemukan bahwa penggunaan strategi Example NonExample dapat meningkatkan keterampilan siswa dalam menulis teks deskriptif melalui beberapa proses yakni; memberikan pemahaman kepada siswa, dan membantu siswa dalam menulis. Hasil dari proses tersebut meliputi peningkatan yang besar pada indikator menulis yakni kosakata, isi/ide, dan struktur menulis. Hal ini dapat terlihat dari peningkatan nilai rata-rata siswa pada nilai awal (basic score) adalah 56, kemudian pada tes pertama adalah 62.5, dan pada tes kedua adalah 79.4. Adapun faktor-faktor yang mempengaruhi perubahan peningkatan kemampuan menulis siswa dalam teks deskriptif adalah materi, media, dan strategi pembelajaran. Maka dapat disimpulkan bahwa penerapan strategi Example Non-example pada pengajaran menulis teks deskriptif dapat memberikan hasil yang positif dengan meningkatnya kemampuan menulis siswa.

Key Words: Writing Skill, Example Non-example, Descriptive Text

\section{INTRODUCTION}

English has become the primary language of communication. It is spoken by millions of people all over the world. English has become the dominant language in many fields of activity such as industry, military, business, tourism, transportation, sports, international relationship, etc. In Indonesia, English is adopted as the foreign language. English involves into education curriculum that every school runs. It becomes a local content in elementary school, a compulsory subject in junior and senior high school and a complementary subject of the higher education institution. This is because of the situation we are facing now; globalization era, which is very competitive. According to Hyland (2002: 53), writing is seen as personal empowerment as it provides access to social and economic benefits, but it is also defined in public discourse in terms of its opposite: the personal stigma attached to 'illiteracy'.

In Indonesia, English is generally taught as a foreign language. Foreign language is a language that is not used as a communication tool in a particular country where the language is taught. Foreign language is usually taught as one of the subjects in the school with the goal of communicating as well as mastering four basic language skills (listening, reading, speaking and writing). Formally, English as a foreign language is taught at the age of independence which is in line with the decision of Indonesia Minister of Education and Culture in 1967.

In Indonesian educational curriculum, students of senior high school are taught some text types of English. Each of them has characteristics that students should understand. Teaching writing to senior high school students is actually different from junior high school or elementary school students. The teacher as a 
Al-Ishlah: Jurnal Pendidikan - ISSN: 2087-949o (p); 2597-940X (e)

Vol. 11, No. 1 (2019)

facilitator should understand students' characteristics and classroom condition before teaching learning process starts. The implementation of active learning is also explained by Lufri and Rahmi (2016) who state that active learning should be developed. Besides, all preparations must be prepared. They are lesson plans, materials that will be taught and teaching methods that will be implemented. In learning a foreign language, writing is one of important skills that should be emphasized and practiced regularly. Students' ability in writing should be improved and the goals of teaching learning activity must be reached.

Fundamentally, writing is learned, rather than taught, and the teacher's best methods are flexibility and support. This means responding to the specific instructional context, particularly the age, first language and experience of the students, their writing purposes, and their target writing communities, and providing extensive encouragement in the form of meaningful contexts, peer involvement, prior texts, useful feedback and guidance in the writing process (Hyland 2002: 78). However, Jusman (2014: 1) says, "Writing is a process of transferring idea, feeling, and thought into written from by giving more attention to the use of language as correctly as possible".

When someone hears the word writing, he will think about text. Mayers in Graeme Harper and Jeri Kroll (2008: 72) states that writing is a way to produce language you do naturally when you speak. Writing is speaking to other on paper or on computer screen. Writing is also an action, a process of discovering and organizing your ideas, putting them on a paper and reshaping and revising them. ${ }^{1}$ Writing is a form of thinking. It means that writing is an activity to express ideas, issues, events, feeling or thinking to the other through written form. According to Laini (2014: 1) claims that form of communication where people are able to express freely about their ideas, feelings, and experiences is called writing. Writing can be defined as communication act, a way of sharing observation, thought, or ideas with ourselves and others. It is a tool of thinking. By writing, we can tell about people, remember the ideas. Based on the statement above, it can be concluded that writing is expressing ideas, facts, feeling, experience, and thought in written form.

One of writing texts that was taught in school was a descriptive text. According to Titi (2007: 28), descriptive text is kind of text that describes a particular person, thing, or place. So, the thing or place that is described should be clear and specific. The social function of descriptive text is describing a particular person, thing, or place. It means that descriptive text deals with a description of an object that allows the reader to describe something specifically.

Based on the observation that was conducted by researcher on $4^{\text {th }}$ June, 2016 at Vocational Madrasah Aliyah Adzqia Belimbing, there was an educational problem that occurred there related to writing a descriptive text. Researcher found 
Al-Ishlah: Jurnal Pendidikan - ISSN: 2087-949o (p); 2597-940X (e)

Vol. 11, No. 1 (2019)

that students in the class X MAK. During the English learning was on going, many of them who had not been able to write well, they still had difficulties in writing descriptive text, such as they did not master the grammar, could not generate idea, and did not master in vocabulary. The phenomena were proved when the researcher gave the writing test; their total mean sore was only 56. It makes the result learning of the class is still low and do not reach KKM that is 75 .

Example non-example is a strategy of learning that uses pictures as media to deliver the learning material. The Examples-Non-Examples strategy is a strategy that uses pictures as a media to encourage students to speak and to learn critical thinking by solving problems through examples (Kagan, 1992: 76 . In addition, Buehl (1996) says that one advantage of examples non examples is students engage in a discovery process, which encourages them to develop the concept of progressively through the experience of examples and non- examples. The purpose of this strategy is to motivate the students in learning critically by solving the problems in an example of the pictures presented. It is in line with Brigs (2001) who state that the contrast pictures are very important to support discovery learning. It is a good problem solving for students in learning process. According to Ruswinarsih (2015: 2), "Pictures is a painting, drawing, sketch of something, the using of picture as a media in learning are designed so that the students can analyze the picture to describe the content of a picture briefly. According to Hosnan (2014), the example non-example method includes in cooperative learning. Moreover, it is a good method in this research. The using of picture as a media in learning is designed so that the students can analyze the picture to describe the content of a picture briefly. Thus, this strategy emphasized in the context of analysis of the students, gives students idea, and helps them in using vocabulary (Huda 2014: 234).

Based on the explanation above, the purposes of this research are (1) to find out the extent to what Example non-example strategy can improve students' writing skill of descriptive text at Grade X of Madrasah Aliyah Kejuruan Adzqia, and (2) to find out the factors that influence the changes of students' writing skill of descriptive text by using example non-example strategy at Grade $\mathrm{X}$ of Vocational MA Adzqia Belimbing.

\section{METHOD}

This research was a classroom action research. This research was conducted to improve the students' writing skill by using example non-example strategy. This research was done in two cycles which involved three meetings for one cycle. It was done by admitting the model that is suggested by Kemmis and McTaggart in Burns (2010: 9). They propose "the model of classroom action 
Al-Ishlah: Jurnal Pendidikan - ISSN: 2087-949o (p); 2597-940X (e)

Vol. 11, No. 1 (2019)

research which involves planning, action, observation and reflection". The researcher worked collaboratively with other English teacher to get better result.

This research was conducted at MAK ADZQIA Belimbing, Batang Gansal Subdistrict of Indragiri Hulu. This research had been done on August, $1^{\text {ist }}$ to $29^{\text {th }}$ 2016. The participants were students at class X MAK Adzqia 2015/2016 Academic year consisting of 27 students. There were four instruments in this research; writing test, observation checklist, field notes and interview. The data were analyzed quantitatively and qualitatively.

\section{FINDING AND DISCUSSION}

The improvement of students' writing score is the main indicator of the success in using Example non-example strategy. In the first writing test in Cycle I, the result of the test showed that the average score of each writing indicator was higher than basic score. They could achieve an improvement from one meeting to other meetings. The score started on grammar 50 in the first meeting of cycle 1 . Then, it improved throughout the meetings. Finally, in test 1 the score of the students' skill in writing descriptive text could reach 51.8. The score indicated that the students are able to write narrative text by using animation video. However, the average score for cycle 1 was still 62.8. Therefore, more treatment in cycle two was needed to improve the score.

The improvement of students' writing skill could be seen by the result of the students' writing test in the following graph:

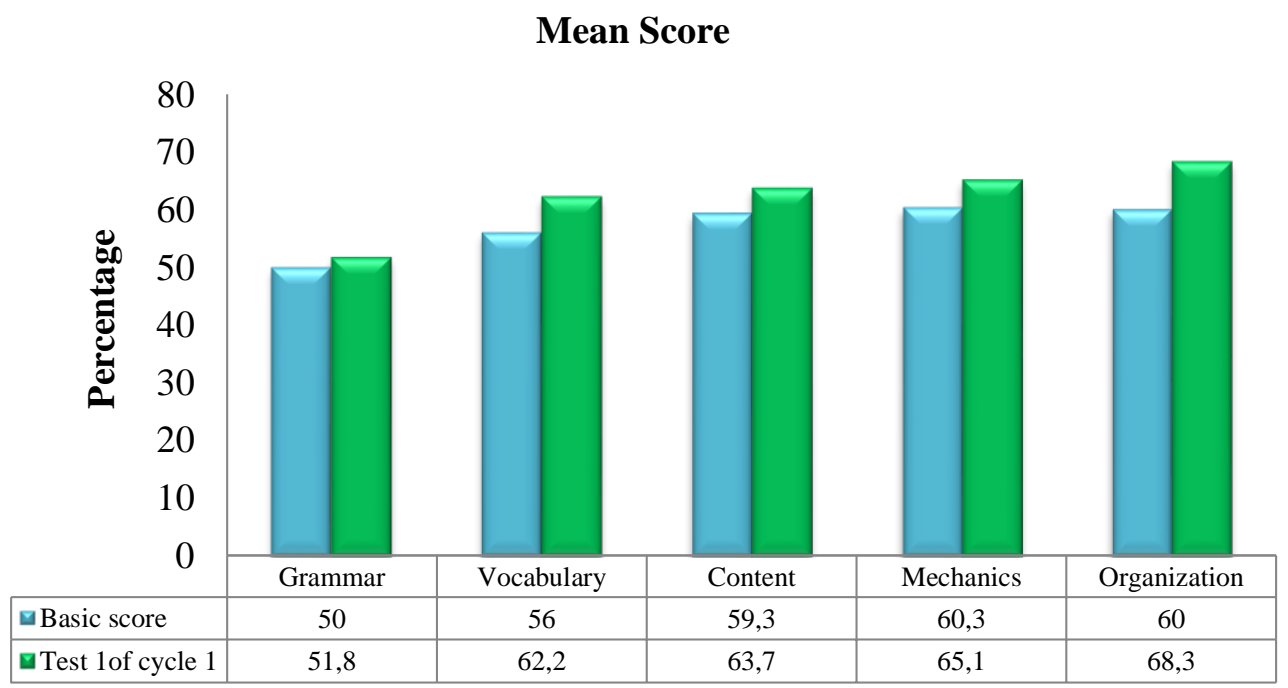

Graph 1. The Improvement of Students' Mean Score per Indicator of Writing Test in Basic Score and Test 1 at the End of Cycle 1 
Al-Ishlah: Jurnal Pendidikan - ISSN: 2087-949o (p); 2597-940X (e)

Vol. 11, No. 1 (2019)

From the graph, it was clear that after the implementation of Example Non-Example strategies in teaching writing descriptive text, the students' writing skill improved for all of indicators of writing skill. It was be referred by their mean score on test 1 at the end of cycle 1 after the implementation of Example Non-Example strategies the score was higher. All indicators were still unsatisfied. They were lower than the criteria of standard achievement, namely 75 . It indicates that the students' writing skill still is low or on fair level. Regarding to the data above, it determines the students' writing ability at descriptive text for the cycle I. The ability of students became apparent that they could improve their writing skills through the use of Example Non-Example strategies with picture as a medium. They can reach a development from one meeting to another. Throughout the meeting, finally, in the first test, the ability to write descriptive texts that the student could reach is 62.8. Therefore, treatment in cycle two was required to increase the value.

From the description above, some of the plans should be developed as a reflection of activity in order to have an increase in students' writing skill. Some issues are still found in the application of student activities through strategy of Example Non-Example in cycle 1 they are:

1. Students paid less attention to the teacher's explanation, making it unclear to them.

2. The topic was given must be better known by the students in order to get a better idea and ease in writing.

3. Students still had problems in grammar, vocabulary, content, and organization.

4. It was seen that the increase in the results of the writing was not completely satisfactory.

As a result, the revise plan on Cycle II was better to improve the students' writing skill of narrative text related to all writing skill indicators. The improvement of students' writing skill could be seen by the result of the students' writing test in the following graph: 
Al-Ishlah: Jurnal Pendidikan - ISSN: 2087-949o (p); 2597-940X (e)

Vol. 11, No. 1 (2019)

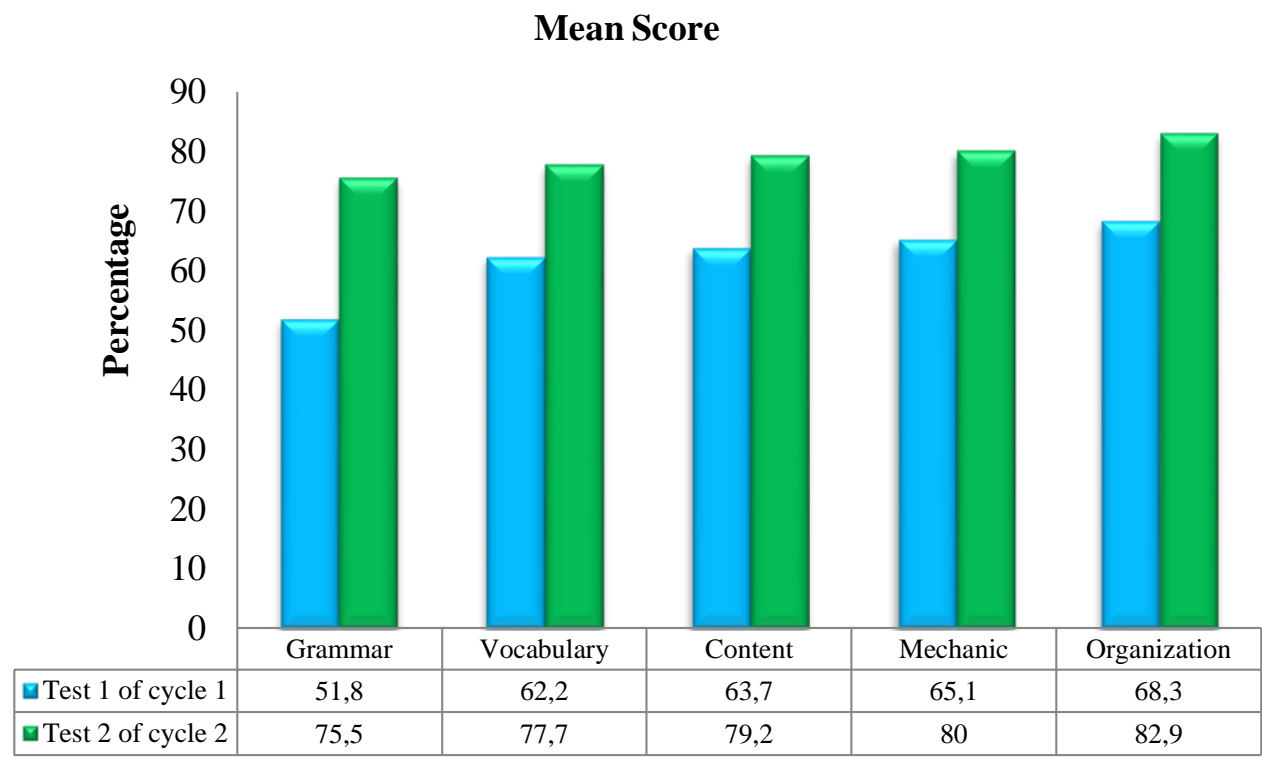

\section{Graph 2. The Improvement of Students' Mean Score per Indicator of Writing Skill on Test 1 at the End of Cycle 1 and Test 2 at the End of Cycle 2}

From the graph, it was clear that after the implementation of Example nonexample strategy in teaching writing in cycle 2, the students' writing skill was improved for all of indicators of writing skill. It was referred by their mean score of test 1 at the end of cycle 1 as higher than and their mean score of test 2 at the end of cycle 2. In this cycle, the students' mean score of the students' writing in Grammar was 75.5. It was higher than the minimum standard of English subject at the researcher's school, namely 75 . It could be implied that, at the cycle 2 , the students attained a good progress and a significant improvements in writing skill by using Example non-example strategy. The data obtained in the second cycle proves that there is an increase in students' writing skills by using Non-Example Example strategy compared with those in the first cycle test. The graph below will show you a comparison of results improvement from basic score to the second cycle.

The above data shows the difference between the average value of the basic value, the value of the test I and II tests. As evidence, in which the initial value prior to the implementation of the Example Non-Example strategies in their writing class, students are only able to get the average score of 56 that score shows that results are still bad. Therefore, it requires the implementation of a strategy or media to improve outcomes of writing. Then after several improvements in the first cycle, students can increase the value of the average writing skills becomes 62.8 , that can be explained that students have an increase 
Al-Ishlah: Jurnal Pendidikan - ISSN: 2087-949o (p); 2597-940X (e)

Vol. 11, No. 1 (2019)

after the implementation of the strategy Example Non-Example in a writing class. Because the results of the students in the first cycle cannot reach the minimum completeness criteria, research should continue into the second cycle. After giving the test, it was found that the average score of students' writing improved significantly, that is 79.4. The value is higher than minimum completeness criteria in the subject of English at the researchers' school, namely 75. It can be stated indirectly, at a meeting II, students acquire a good process and a significant increase in their ability to write by using Example Non-Example strategy.

Regarding the data above and analysis, the researchers found that the use of Non-Example Example strategy contributed positively to the improvement of students' writing. The data was enough to prove that the process of teaching and learning was effective in solving the problem of students' writing skill. After the improvement of students during the three meetings, the researchers tested the students' writing skill on descriptive text at the end of the second cycle. The result of students in these tests was satisfactorily, because students can achieve an average score that is higher than the minimum completeness criteria. It can be concluded that they could improve their writing ability by using Example NonExample strategy. In other words, this strategy is effective for the students' writing skill. Lastly, it can be categorized as a successful research.

In addition, to answer the second question of this research, which relates to the factors affecting the increase of students' writing on the descriptive text using the example of non-example strategy, is based on observations and interviews in this study. These factors are (1) materials, (2) media, and (3) learning strategies. The material is an important factor affecting the increase in students' writing ability. Teachers bring materials during the learning process that has been prepared in advance. When the teacher gave a different picture to be described in each meeting, the results of students' writing skills in descriptive text increased. Media is one of the factors affecting the increase in students' writing ability. Researcher used Example Non- Example strategy where the images are the media. It can be proven that the media have an important role in improving students' ability to write descriptive text. Learning strategies can affect the ability of students to write descriptive text. The strategy used by the teacher makes writing easier and more enjoyable. Through discussion on learning strategy, it could help students to determine a new vocabulary. This means that the learning strategies used by teachers in the learning process can help students to write and motivate them. In conclusion, learning strategies can boost students' writing ability in descriptive text. 
Al-Ishlah: Jurnal Pendidikan - ISSN: 2087-949o (p); 2597-940X (e)

Vol. 11, No. 1 (2019)

\section{CONCLUSION}

This research was conducted to determine the extent of example nonexample strategy in improving students 'writing skill of descriptive text and what factors can influence changes in students' writing ability in descriptive text by using the example of non-example strategy of class $\mathrm{X}$ at Madrasah Aliyah Vocational Adzqia Belimbing. After analyzing the quantitative and qualitative data,it can be summed up as follows: The use of Example non-example strategy improves students' writing on descriptive text in class X Madrasah Aliyah Vocational Adzqia Belimbing. This is supported by quantitative data which showed the improvement of students' writing ability in each indicator; grammar, vocabulary, mechanics, content, and organization, as well as the average score of their basic score, the writing test in the first and second cycle. The average score of the basic score was only 56, in the first cycle average score of students increased in 62.8 and in the second cycle increased to 79.4 This means that the average score of students in the second cycle achieve the minimum completeness criteria English at Madrasah Aliyah Vocational Adzqia Belimbing is 75.

There are three factors that change the improvement in students' writing skills in the descriptive text. These factors are material, media and learning strategies. In line with the above factors, researcher conducted the research through the better approach. He controlled and helped students in writing descriptive text. He also discussed the students' mistakes in every meeting to improve the writing skills to the next meeting.

Based on the conclusions and the implications above, the researchers intend to provide advice, as follows: Researcher as an English teacher is advises to continue using the example of non-example strategy in teaching writing and in the future researcher advice to conduct relevant research related to the use of nonexample strategy example for other styles and abilities in teaching English.

\section{REFERENCES}

Briggs, C. L. (2001). "Discovery Learning, Cognitive Psychology of". Elsevier: International Encyclopedia of the Social Science.

Buehl. (1996). Http//id. Wordpress. Com/model-model pembelajaran koperatif.Google.

Burns, Anne. (2010). Doing Action Research in English Language Teaching: A

Guide for Practitioners. Routledge: ESL \& Applied Linguistics Professional Series. 
Al-Ishlah: Jurnal Pendidikan - ISSN: 2087-949o (p); 2597-940X (e)

Vol. 11, No. 1 (2019)

Graeme Harper and Jeri Kroll. (2008). Creative Writing Studies: Practice, Research and Pedagogy. Ontario: Multilingual Matters Ltd.

Hyland, Ken. (2002). Authority and Invisibility: Authorial Identity in Academic Writing. Journal of Pragmatics 34.

Hosnan. (2014). Pendekatan dan Kontekstual dalam Pembelajaran Abad 21. Jakarta: Ghalia Indonesia.

Huda, Miftahul. (2014). Model Model Pengajaran dan Pembelajaran. Jogjakarta: Pustaka Belajar. Indonesia Minister of Education and Culture. 1967. https://www.google.com/search?q=Indonesia+Minister+of+Education+an $\mathrm{d}+$ Culture+in+1967.\&oq=Indonesia+Minister+of+Education+and+Culture + in+1967.\&aqs=chrome..69i57.1205j0j7\&sourceid=chrome\&ie=UTF-8.

Jusman, Mohtar, et al. (2014). The Developing Students' Ability In Writing Procedure Text By Using Sequences Pictures. Jurnal of English Language Teaching Society (ELTS). Vol. 2.

Kagan, S. (1992). The Structural Approach to Cooperative Learning in Cooperative learning: A Response to Linguistics and Cultural Diversity.Edited by Daniel. London: Longman Inc.

Kemmis, and Mc. Taggart. (1988). The Action Research Planner. Victoria: Deakin University.

Laini, Bintari Rahmadhani Nur. (2014). The Application of Think Pair Share in Improving Writing Skill of The Eighth Grade Students of SMPN 9 Denpasar in Academic Year 2013/2014. Denpasar: Mahasaraswati Denpasar University.

Lufri, Sudirman, S., and Rahmi, S. (2016). "Mengembangkan Skill Mengajar (Teaching Skill) Mahasiswa Calon Guru Menggunakan Multy Strategies". Ta'dib, 15(1).

Ruswinarsih. 2015. The Use of Pictures In Improving Writing Procedure Text Ability of The First Students' of SMPN 5 Dumai. Journal ELTIN Vol. 3.

Titi N, Rinawati, Ana Mulia. (2007). Seri Pendalaman Materi Bahasa Inggris SMP dan MTs. Jakarta: Gelora Aksara Pratama. 